\title{
Phytochemical Screening and Antibacterial Assay of extracts of different parts of Moringa oleifera Lam
}

\author{
Nishu $^{1}$, Chandrawati Jee ${ }^{1}$ and Ravi Kumar ${ }^{2 *}$ \\ ${ }^{1}$ Department of Biotechnology, A.N. College, Patna, Magadh University, \\ Bodh Gaya-824234, Bihar, India \\ ${ }^{2}$ Department of Horticulture (Vegetable and Floriculture), Bihar Agricultural University, \\ Sabour-813210, Bhagalpur,Bihar, India
}

*Corresponding author

\section{A B S T R A C T}

Keywords

Drumstick phytochemicals, Antimicrobial resistance

Article Info

Accepted: 08 January 2020 Available Online: 10 February 2020
Antibiotic resistance remains the serious concern to the global health. Antibiotic are becoming less effective against various pathogenic organism. The present study was aimed to evaluate antibacterial efficacy of Leaf, Flower and bark of Moringa oliefera (Drumstick).This result shows methanolic extracts of leaf had best zone of inhibition against E.coli and Streptococcus pneumonia and the most susceptible bacteria was found to be S. aureus pseudomonas Ethyl acetate extract of bark against Pseudomonas showed better result than other solvent $(12 \mathrm{~mm})$. Zone of inhibition of petroleum ether and ethyl acetate extract of flower shows better zone against Streptococcus pneumoniae. Hence it proves that selected part of Moringa oleifera contains bioactive components which are antibacterial in nature.

\section{Introduction}

The increasingly large numbers of bacteria that are developing resistance against orthodox antibiotics pulls attention of researchers toward herbal antimicrobial molecules in hope that they may provide useful leads into anti-infective drug with least side effects. Several secondary metabolites were isolated from plant which includes terpenoids, steroids, alkaloids, tannins, benzophenones, coumarins and flavonoids. These new herbal phytochemical substances can also serve as templates for producing more effective drugs through semi-synthetic and total synthetic procedure.

Moringa oleifera (Lam) is the most cultivated species of a single genus found in Moringaceae family, commonly known as Drumstick. Other common names of this plant are horse radish tree, benzolive tree, mother's 
best friend, marango, Mulangay, Sajna or Ben oil tree. Moringa species have been utilized by Traditional medicine practitioners in curing various diseases as it has medicinal values (Rathi et al., 2004). It is considered as Miracle tree as all the parts of the plant are useful for human. It is also known as multipurpose plant due to its various functions almost every parts of the plant are exploring by many in different industries. Some of the valuable uses of Moringa oleifera are medicine, nutrition, water management, livestock feed, biodiesel and landscaping among others (Bennet, et al., 2003).

Many part of the plant such as leaves, fruits, roots were used as vegetables (Siddhuraju, et $a l, 2003)$.This plant has plethora of Minerals and vitamins (Latida, et al.,2013). Different studies have showed that various parts of Moringa oleifera such as stem, flowers, bark, roots as well as seeds have antimicrobial activities (Lockett,et al.,2000 and Fahey,et al,2005). Moringa oleifera have been considered as antimicrobial agent after the discovery of several Antimicrobial bioactive components with inhibitory activity against many pathogenic microorganisms (Fozia, et al.,2012). leaves are known to have biological properties due to presences of useful phytochemicals compounds such as saponins, flavonoids, tannins and other phenolic compounds that have antimicrobial properties (Bako, et al.,2010).The seed pods (fruits) of the Moringa oleifera tree are one of the most nutritive and useful parts of this versatile plant.

The root and bark of young trees are considered rubefacient, stomachic carminative, vesicant and abortifacient. The flowers and roots contain an antibiotic that is highly effective in the treatment of cholera. Torres-Castillo, et al.,2013 stated that the antioxidant activities of Moringa plant extracts is due to the presence of polyphenolic compounds, which can act as great antimicrobial agents in a quantum of crucial phytoconstituents such as tannins, saponins, alkaloids, steroidal aglycones, reducing sugars, terpenoids, and so on, that act as a cardiac and circulatory stimulants, possess anti-tumour, antipyretic, anticonvulsant, antiinflammatory (Lockette et al, 2000), antiulcer, antispasmodic, antidiabetic, diuretic, antihypertensive, cholesterollowering, antioxidant, antifungal, abortifacient, antibacterial (Anwar and Rashid, 2007).

Antimicrobial activity from the ethanolic extract of leaves, seeds and flowers of Moringa oleifera against microorganisms like Escherichia coli, Klebsiella pneumoniae, Enterobacter spp, Proteus mirabilis, Pseudomonas aeroginosa, Salmonella typhi A, Staphylococcus aureus, Streptococcus and Candida albicans (Renitta, et al.,2009). Moringa leaves have been reported to contain more vitamin A than carrots, more calcium than milk, more iron than spinach, more vitamin $\mathrm{C}$ than oranges, and more potassium than bananas, and that the protein quality of Moringa leaves rivals that of milk and eggs.

The solo aim of the present study is an attempt to explore the potentiality of Moringa oliefera leaves, flower and bark (Methanol, Petroleum ether, Ethyl acetate \& Aqueous) extracts Phytochemical \& Antibacterial angle. The Antibacterial activity of above extracts was evaluated by using gram positive \& gram negative strain of human pathogenic bacteria.

\section{Materials and Methods}

\section{Collection of plant material}

The plant material of Moringa oleifera (Fresh leaves, flower and bark) used in study were collected from botanical garden of A.N.College, Patna, Bihar, India. 


\section{Preparation of plant extracts}

Fresh material of the plant samples were collected, cleaned, washed, air dried and homogenized to a fine powdered using mechanical stirrer and stored in airtight bottle. $25 \mathrm{gm}$ of collected powdered form of leaves, flower, bark weighed and extracted with Ethanol, Methanol, Petroleum ether, ethyl acetate and aqueous extracts by soaking the powdered materials in $200 \mathrm{ml}$ of solvents \& run in Soxhlet. The process of extraction continues until solvent becomes transparent. Extract was dried by rotary evaporator at $40^{\circ} \mathrm{C}$ for 36 hours. Extract yield were weighed and mentioned in table 1 . The extracts were kept in sterile bottles under refrigerated condition until use.

\section{Identification, selection and maintenance of test bacteria}

Four bacterial cultures of Escherichia coli, Streptococcus pneumonia (Gram negative Bacteria) Staphylococcus aureus and pseudomonas aeruginosa (Gram positive Bacteria) were selected for antibacterial assay. These clinical bacteria were brought from laboratory of Microbiology Department of Patna Medical Hospital. The isolates were cultured and identified by using microscopy (by Gram staining procedures), colony examination and biochemical tests (BPC, 1994). The subculture was maintained on nutrient broth at $37^{\circ} \mathrm{c}$ and were cultured on nutrient agar to perform Antibacterial activity.

\section{Phytochemical screening}

The qualitative Phytochemical screeningof the extracts was done to assess the presence of the following active ingredient: Alkaloid, Flavonoid, Glycosides, Steroids, Polyphenol, Terpenoids, Saponins and Tannins, (Sofowora, et al,1989; Trease, et al,1989).

\section{Antibacterial activity}

Antibacterial activity of selected plant parts extracts was carried out by using agar disc diffusion method in nutrient agar media with little modifications. About $25 \mathrm{ml}$ of media was poured into each Petri plate. After solidification of media, the bacteria were inoculated by spreader on the surface of the plates. $6 \mathrm{~mm}$ disc of Whatman No. 1 filter paper were loaded with $25 \mu \mathrm{l}$ of plant different solvent extract along with positive control and negative control and air dried.The discs were placed in the medium and after incubation at $37^{\circ} \mathrm{C}$ for $24 \mathrm{hrs}$, zone of inhibitions was observed and measured in mm. (Murray, 2009).

\section{Results and Discussion}

\section{Phytochemical screening}

The selected parts (Leaves, Flower, Bark) of different extracts of Moringa oleifera Lam were dried, finely powdered and extracted, used for this study (Table 1). The results of the phytochemical analysis revealed varying constituents of these extracts. Alkaloids, glycosides, terpenoids, saponins and tannins were detected in all extracts of leaf but aqueous extract only contain flavonoid and steroids.(Table 2). Flower extract is devoid of steroids, terpenoids and tannins (Table 3) while bark extract does contain steroids (Table 4).

\section{Antibacterial testing}

The antimicrobial assay results revealed that $M$. oleifera extracts exhibited antimicrobial activities against Escherichia coli, Staphylococcus aureus, Streptococcus pneumonia and Pseudomonas aeruginosa. The Moringa oleifera, leaf methanolic extract was active against Escherichia coli and Streptococcus pneumonia but shows less 
active against Staphylococcus aureus and Pseudomonas aeruginosa. Standard Amikacin (controls) inhibited the test organisms by $100 \%$ at $10 \mathrm{mg} / \mathrm{ml}$ concentrations respectively (Tables 5, 6 and 7).

Fig. shows that in Moringa oleifera leaves, all extracts had higher antibacterial activity against E.coli compared to S.aureus. In Moringa oleifera flower, all extract had higher antibacterial activity against $S$. pneumonia. Ethyl acetate showed highest antibacterial activity against four microorganisms tested. In Moringa oleifera bark, methanol and petroleum ether extract showed better antibacterial property in comparison to others in E. coli (12mm).

In case of pseudomonas, ethyl acetate showed better result than other solvent $(12 \mathrm{~mm})$. Petroleum ether and ethyl acetate extract was most active against Streptococcus pneumonia. Moringa leaf was active against pathogenic bacteria as compared to flower and bark.

Table.1 Dry weight of extract after drying in Rota Vapour (gm/100gm)

\begin{tabular}{|c|l|c|c|l|l|l|}
\hline Sl.No. & $\begin{array}{l}\text { Sample } \\
(\mathbf{1 0 0 g})\end{array}$ & $\begin{array}{c}\text { Ethanol } \\
\text { Extract } \\
(\mathbf{g m} / \mathbf{1 0 0 g m})\end{array}$ & $\begin{array}{c}\text { Methanol } \\
\text { Extract } \\
(\mathbf{g m} / \mathbf{1 0 0 g m})\end{array}$ & $\begin{array}{l}\text { Ethyl } \\
\text { Acetate } \\
\text { Extract }\end{array}$ & $\begin{array}{l}\text { Aqueous } \\
\text { Extract } \\
(\mathbf{g m} / \mathbf{1 0 0 g m})\end{array}$ & $\begin{array}{l}\text { Petroleum's } \\
\text { Ether } \\
\text { (gm/100gm) }\end{array}$ \\
\hline $\mathbf{1 .}$ & Leaf & 14.26 & 17.72 & 11.82 & 7.27 & 10.84 \\
\hline $\mathbf{2 .}$ & Bark & 9.4 & 10.24 & 8.22 & 5.42 & 9.4 \\
\hline $\mathbf{3 .}$ & Flower & 13.2 & 8.7 & 8.5 & 7.34 & 12.2 \\
\hline
\end{tabular}

Table.2 Phytochemical screening of selected solvent of leaf extract

\begin{tabular}{|l|l|c|c|c|c|c|}
\hline Sl. No. & Phytochemicals & Methanol & Ethanol & Petroleum ether & Ethyl acetate & Aqueous \\
\hline $\mathbf{1}$ & Alkaloids & + & + & + & + & - \\
\hline $\mathbf{2}$ & Flavonoids & + & + & + & + & + \\
\hline $\mathbf{3}$ & Glycosides & + & + & + & + & - \\
\hline $\mathbf{4}$ & Steroids & + & + & + & + & + \\
\hline $\mathbf{5}$ & Polyphenol & + & + & + & + & - \\
\hline $\mathbf{6}$ & Terpenoids & + & + & + & + & - \\
\hline $\mathbf{7}$ & Saponins & + & + & + & + & - \\
\hline $\mathbf{8}$ & Tannin & + & + & + & + & - \\
\hline
\end{tabular}

$(+)$ indicates presences (-) indicates absences 
Table.3 Phytochemical screening of selected solvent of flower extract

\begin{tabular}{|r|l|c|c|c|c|c|}
\hline Sl. No. & Phytochemicals & Methanol & Ethanol & Petroleum ether & Ethyl acetate & Aqueous \\
\hline $\mathbf{1}$ & Alkaloids & - & - & - & - & + \\
\hline $\mathbf{2}$ & Flavonoids & - & - & + & + & + \\
\hline $\mathbf{3}$ & Glycosides & + & - & + & + & - \\
\hline $\mathbf{4}$ & Steroids & - & - & - & - & - \\
\hline $\mathbf{5}$ & Polyphenol & + & + & - & + & - \\
\hline $\mathbf{6}$ & Terpenoids & - & - & - & - & - \\
\hline $\mathbf{7}$ & Saponins & + & + & - & - & + \\
\hline $\mathbf{8}$ & Tannins & - & - & - & - & - \\
\hline
\end{tabular}

(+) indicates presences (-) indicates absences

Table.4 Phytochemical screening of selected solvent of bark extract

\begin{tabular}{|l|l|c|c|c|c|c|}
\hline Sl. No. & $\begin{array}{l}\text { Phyto } \\
\text { chemicals }\end{array}$ & Methanol & Ethanol & Petroleum ether & Ethyl acetate & Aqueous \\
\hline $\mathbf{1}$ & Alkaloids & - & - & - & + & - \\
\hline $\mathbf{2}$ & Flavonoids & + & + & + & + & + \\
\hline $\mathbf{3}$ & Glycosides & + & - & + & - & + \\
\hline $\mathbf{4}$ & Steriods & - & - & - & - & - \\
\hline $\mathbf{5}$ & Polyphenol & - & + & - & + & - \\
\hline $\mathbf{6}$ & Terpenoides & + & - & - & - & - \\
\hline $\mathbf{7}$ & Saponins & + & - & - & - & + \\
\hline $\mathbf{8}$ & Tannins & - & + & - & - & - \\
\hline
\end{tabular}

$(+)$ indicates presences (-) indicates absences

Table.5 Leaf extract antibacterial analysis on selected bacterial strain $(10 \mathrm{mg} / \mathrm{ml})$

\begin{tabular}{|l|l|c|c|c|c|c|c|c|}
\hline $\begin{array}{l}\text { Sl. } \\
\text { No }\end{array}$ & $\begin{array}{l}\text { Bacterial } \\
\text { Strain }\end{array}$ & $\begin{array}{c}\text { P+ } \\
\text { Control }\end{array}$ & $\begin{array}{c}\text { N- } \\
\text { Control }\end{array}$ & Methanol & Ethanol & $\begin{array}{c}\text { Petroleum } \\
\text { ether }\end{array}$ & $\begin{array}{l}\text { Ethyl } \\
\text { acetate }\end{array}$ & Aqueous \\
\hline $\mathbf{1}$ & $\begin{array}{l}\text { E.Coli } \\
\mathbf{2}\end{array}$ & $32 \mathrm{~mm}$ & $0 \mathrm{~mm}$ & $12 \mathrm{~mm}$ & $10 \mathrm{~mm}$ & $8 \mathrm{~mm}$ & $10 \mathrm{~mm}$ & $6 \mathrm{~mm}$ \\
\hline $\begin{array}{l}\text { Streptococcus } \\
\text { pneumonia }\end{array}$ & $28 \mathrm{~mm}$ & $0 \mathrm{~mm}$ & $12 \mathrm{~mm}$ & $9 \mathrm{~mm}$ & $6 \mathrm{~mm}$ & $8 \mathrm{~mm}$ & $3 \mathrm{~mm}$ \\
\hline $\mathbf{3}$ & $\begin{array}{l}\text { Pseudomonas } \\
\text { aeruginosa }\end{array}$ & $24 \mathrm{~mm}$ & $0 \mathrm{~mm}$ & $10 \mathrm{~mm}$ & $7 \mathrm{~mm}$ & $10 \mathrm{~mm}$ & $8 \mathrm{~mm}$ & $2 \mathrm{~mm}$ \\
\hline $\mathbf{4}$ & $\begin{array}{l}\text { Staphylococcus } \\
\text { aureus }\end{array}$ & $25 \mathrm{~mm}$ & $0 \mathrm{~mm}$ & $12 \mathrm{~mm}$ & $10 \mathrm{~mm}$ & $8 \mathrm{~mm}$ & $10 \mathrm{~mm}$ & $6 \mathrm{~mm}$ \\
\hline
\end{tabular}

Note: $-\mathrm{P}+$ Positive Control $=$ Amikacin $(10 \mu \mathrm{l})$ and $\mathrm{N}-$ Negative Control $=$ Sterilized of distilled Water 
Table.6 Flower extracts antibacterial analysis on selected bacterial strain (mm)

\begin{tabular}{|l|l|c|c|c|c|c|c|c|}
\hline $\begin{array}{l}\text { Sl. } \\
\text { No. }\end{array}$ & $\begin{array}{l}\text { Bacterial } \\
\text { Strain }\end{array}$ & $\begin{array}{c}\text { P+ } \\
\text { Control }\end{array}$ & $\begin{array}{c}\text { N- } \\
\text { Control }\end{array}$ & Methanol & $\begin{array}{c}\text { Petroleum } \\
\text { Ether }\end{array}$ & Ethanol & Aqueous & $\begin{array}{c}\text { Ethyl } \\
\text { acetate }\end{array}$ \\
\hline $\mathbf{1}$ & E.coli & $30 \mathrm{~mm}$ & $7 \mathrm{~mm}$ & $10 \mathrm{~mm}$ & $11 \mathrm{~mm}$ & $10 \mathrm{~mm}$ & $2 \mathrm{~mm}$ & $12 \mathrm{~mm}$ \\
\hline $\mathbf{2}$ & $\begin{array}{l}\text { Streptococcus } \\
\text { pneumonia }\end{array}$ & $30 \mathrm{~mm}$ & $7 \mathrm{~mm}$ & $8 \mathrm{~mm}$ & $12 \mathrm{~mm}$ & $12 \mathrm{~mm}$ & $10 \mathrm{~mm}$ & $12 \mathrm{~mm}$ \\
\hline $\mathbf{3}$ & $\begin{array}{l}\text { Pseudomonas } \\
\text { aeruginosa }\end{array}$ & $30 \mathrm{~mm}$ & $7 \mathrm{~mm}$ & $10 \mathrm{~mm}$ & $8 \mathrm{~mm}$ & $4 \mathrm{~mm}$ & $2 \mathrm{~mm}$ & $10 \mathrm{~mm}$ \\
\hline $\mathbf{4}$ & $\begin{array}{l}\text { Staphylococcus } \\
\text { aureus }\end{array}$ & $30 \mathrm{~mm}$ & $7 \mathrm{~mm}$ & $10 \mathrm{~mm}$ & $12 \mathrm{~mm}$ & $11 \mathrm{~mm}$ & $6 \mathrm{~mm}$ & $12 \mathrm{~mm}$ \\
\hline
\end{tabular}

Table.7 Bark extracts antibacterial analysis on selected bacterial strain (mm)

\begin{tabular}{|l|l|l|c|c|c|c|c|c|}
\hline $\begin{array}{l}\text { Sl. } \\
\text { no. }\end{array}$ & Bacterial Strain & $\begin{array}{c}\text { P+ } \\
\text { Control }\end{array}$ & $\begin{array}{c}\text { N- } \\
\text { Control }\end{array}$ & Methanol & $\begin{array}{l}\text { Petroleum } \\
\text { Ether }\end{array}$ & Ethanol & Aqueous & $\begin{array}{c}\text { Ethyl } \\
\text { acetate }\end{array}$ \\
\hline $\mathbf{1}$ & E.coli & $30 \mathrm{~mm}$ & $7 \mathrm{~mm}$ & $12 \mathrm{~mm}$ & $12 \mathrm{~mm}$ & $7 \mathrm{~mm}$ & $8 \mathrm{~mm}$ & $10 \mathrm{~mm}$ \\
\hline $\mathbf{2}$ & $\begin{array}{l}\text { Streptococcus } \\
\text { pneumoniae }\end{array}$ & $30 \mathrm{~mm}$ & $7 \mathrm{~mm}$ & $8 \mathrm{~mm}$ & $12 \mathrm{~mm}$ & $10 \mathrm{~mm}$ & $2 \mathrm{~mm}$ & $12 \mathrm{~mm}$ \\
\hline $\mathbf{3}$ & $\begin{array}{l}\text { Pseudomonas } \\
\text { aeruginosa }\end{array}$ & $30 \mathrm{~mm}$ & $7 \mathrm{~mm}$ & $6 \mathrm{~mm}$ & $8 \mathrm{~mm}$ & $3 \mathrm{~mm}$ & $6 \mathrm{~mm}$ & $12 \mathrm{~mm}$ \\
\hline $\mathbf{4}$ & $\begin{array}{l}\text { Staphylococcus } \\
\text { aureus }\end{array}$ & $30 \mathrm{~mm}$ & $7 \mathrm{~mm}$ & $11 \mathrm{~mm}$ & $10 \mathrm{~mm}$ & $10 \mathrm{~mm}$ & $10 \mathrm{~mm}$ & $11 \mathrm{~mm}$ \\
\hline
\end{tabular}

Many researchers have proven that Moringa oleifera parts such as bark, stem, flowers, fruit, roots as well as seeds have antimicrobial activities (Fahey, et al.,2005: locket, et al.,2000). Moringa oleifera have been considered as bactericidal agent after the discovery of several antibacterial constituents with inhibitory activity against pathogenic bacteria. Finding of new antimicrobials that would be effective against drug resistant strains, phytochemical screening and antibacterial activity, investigation of the $M$. oleifera selected parts extract were carried out. It is suggested that this plant drug would have enormous health benefits with little side effects that is common with the synthetic drugs. During the course of this research, investigations have founded many phytochemicals bioactive compound with promising antibacterial activity.
Various researchers reported antimicrobial activity of Moringa oleifera against variety of pathogens including $S$. aureus, S. albus, $S$. pyogenes $P$. aeruginosa, Salmonella gallinarum, B.subtilis and E. coli (Thilza,et al.,2010 and Kumar, et al.,2012).Antimicrobial activity from the seeds of Moringa oleifera were assayed for the evaluation of antimicrobial activity against bacterial strains (Pasturella multocida, Escherichia coli, Bacillus subtilis and Staphlocuccus aureus), which was evaluated by Amer Jamil et al., (2008).

Phytochemicals are present in virtually all plant tissues of Moringa oleifera e.g. leaves, roots, stem and fruits (Siddiqui, et al.,2009). Presence of phytoconstituents like alkaloids, flavonoids, tannins, saponins are responsible for antibacterial activity (Patil, et al.,2013). Alkaloids, phenols, flavonoids and glycosides 
have a number of biological activities and strong antibacterial potentials (Robbers et al., 1996). Alkaloids have exhibited promising activity against $H$. pylori (Hadi and Bremner, 2001) and a number of other bacterial strains (Sinha et al., 2001; Saeed and Sabir, 2001; Khan et al., 2001; Kren and Martinkova, 2001) Similarly, a few glycosides have presented with antibacterial activities The antibacterial potential of terpenoids have been documented.

Terpenoids are bioactive molecules which are a part of plants' defence mechanisms as phyto protectants (Morrissey and Osbourn, 1999).Studies have shown that the antimicrobial potential of $M$. oleifera leaves extract may be attributable to the presence of an array of phytochemicals.

This study revealed that Moringa oleifera is highly potential medicinal plant of multiple use. It has high antibacterial property and effective secondary metabolite make them more suitable for newer and safer nutraceutical and pharmaceutical products. Moringa oleifera parts could be good source of drugs that maty be used against bacterial infection if it is found effective and non-toxic in animal trial. Detailed study is needed to investigate the active compounds present in these plant parts having antibacterial activity that may help us to design more effective chemo therapeutic agent to heal bacterial infections. The result strengthens the scientific data base.

\section{Acknowledgement}

The authors are thankful to Principal of A.N College, Patna and Director ITS laboratory New Delhi for providing me laboratory and library facility.

\section{References}

Anwar F, Rashid U. Physiochemical characteristics of Moringa oleifera seeds and seed oil from a wild provenance of Pakistan. Pak $J$ Bot 2007; 1443-1453.

Belguith $\mathrm{H}$, Kthiri $\mathrm{F}$. Inhibitory effect of aqueous extract of Allium sativum. African J Microbiol Res 2010; 4(5): 328-338.

Booth C. The genus Fusarium, Kew Commonwealth Mycological Institute. England: Kew, Surrey; 1971, p237.

Bukar A, Uba A, Oyeyi TI. Antimicrobal profile of Moringa oleifera Lam. extracts against Mal. J Microbiol 2010; 8(2): 59-67.

CI Mboto; ME Eja; AAAdegoke; GDI watt; BEA sikong; ITakon; SM Udo; $\mathrm{M}$ Akeh; Afr. J. Microbiol. Res.,2009, 3(9): 557-559.

Dewagan G, Koley KM, Vadlamudi VP, Mishra A, Poddar A, Hirpurkar SD, Antibacterial activity of Moringa oleifera (drumstick) root bark. J Chem Res 2010; 2(6): 424-428.

Dewagan G, Koley KM, Vadlamudi VP, Mishra A, Poddar A, Hirpurkar SD, Antibacterial activity of Moringa oleifera (drumstick) root bark. J Chem Res 2010; 2(6): 424-428.

F Fozia; R Meenu; T Avinash; K Abdul Arif; F Shahila, J. of Med. plants Res., 2012, 6(27): 4368-4374. doi:10.5897/JMPR12.279

JA Torres-Castillo; SR Sinagawa-García;GC Martínez-Ávila; AB López-Flores;EL Sánchez-González; VE Aguirre-Arzola; RI Torres-Acosta;E OlivaresSáenz,EOsorio-Hernández;A GutiérrezDoes, Inter. J. of Exp. Bot.,2013 82:193-202

JW

Fahey,2005.http://www.TFLjournal.org/ article.

Khan, M.R. et al., (2001). Fitoterapia, 72:575-578.

Khan, M.R. et al., (2003). The Indian 
Pharmacist, 69-72.

Kumar V, Pandey N, Mohan N, Singh RP. Antibacterial \& antioxidant activity of different extract of Moringa oleifera leaves- an in-vitro study. Int J Pharma Sci Rev Res 2012; 12(1): 89-94.

Kumar V, Pandey N, Mohan N, Singh RP. Antibacterial \& antioxidant activity of different extract of Moringa oleifera leaves an in-vitro study. Int J Pharma Sci Rev Res 2012; 12(1): 89-94.

Lockett CT et al., Energy and micronutrient composition of dietary and medicinal wild plants consumed during drought. Study of rural fulani, northeastern Nigeria. Int J Food Sci Nutr; 2000, 51:195-208

Lowell YF. Moringa oleifera: natural nutrition for the tropics, the miracle tree. Dakar,Senegal: Church world service; 1989, p 68.

Murray PR, Rosenthal KS, Pfaller MA (2009). Medical microbiology: Mosby Inc.

Nepolean P, Anitha J, Renitta RE. Isolation, analysis and identification of phytochemicals and antimicrobial activity of Moringa oleifera Lam. Current biotica 2009; 3(1): 3339.

Nepolean P, Anitha J, Renitta RE. Isolation, analysis and identification of phytochemicals and antimicrobial activity of Moringa oleifera Lam. Current biotica 2009; 3(1): 3339.

P Siddhuraju; K Becker,J .Agric. Food Chem.2003, 51:2144-215

Patil SD, Jane Rasika. Antimicrobial activity of Moringa oleifera and its synergism with Cleome viscose. Int J Life Sci 2013; 1(3): 182189.

Patil SD, Jane Rasika. Antimicrobial activity of Moringa oleifera and its synergism with Cleome viscose. Int J Life Sci 2013; 1(3): 182189.

PS Lalida; R, Thidarat; SLVannajan; D Srisulak, J. of Med. and Bioengine.
2013,(2):163-167.

Raheela J, Muhammad S, Amer J, Muhammad A. Microscopic evaluation of the antimicrobial activity of seed extracts of Moringa olefera. Pak J Bot 2008; 40(4):1349-1358.

Raheela J, Muhammad S, Amer J, Muhammad A. Microscopic evalutition of the antimicrobial activity of seed extracts of Moringa olefera. Pak J Bot 2008; 40(4):13491358.

Rathi B, Pathi PA, Baheti AM. Evaluation of aqueous extract of pulp and seeds of Moringa oleifera for wound healing in albino rats. J. Natural Remedies, 2004; 4: $145-149$.

Renitta RE, Anitha J, Napolean P. Isolation, analysis and identification of phytochemicals of antimicrobial activity of Moringa oleifera Lam. 2009; 3(1):33-37.

RN Bennette, FA Mellon, N Foidl, JH Pratt, MS Dupont, L Perkins, PA Kroon. $J$. Agric. food chem, 2003, 57:3546-3553

Robbers, J. et al., (1996). Pharmacognosy and Pharmacobiotechnology, Williams and Wilkins, Baltimore

Siddiqui S, Verma A, Rather AA, Jabeen F, Meghvansi MK. Priliminary phytochemicals analysis of some important medicinal and aromatic plants. Advan Biol Res 2009, 3(5-6): 188-195.

Siddiqui S, Verma A, Rather AA, Jabeen F, Meghvansi MK. Priliminary phytochemicals analysis of some important medicinal and aromatic plants. Advan Biol Res 2009, 3(5-6): 188-195.

Sofowora EA. Medicinal plants and traditional medicine in Africa. New York: John wiley and sons Inc; 1989, p 256-257

SS Bako; JU Okere; AC Etonihu; Y Mohammed; OA Olanisakin; BO Atolaiye; PC Mau, Raw materials 
research and development council: Moringa - A national crop for economic growth and development, 2010,107114.

Thilza IB, Sanni S, Zakari AFS, Sanni MT, Musa BJ. In vitro antimicrobial activity of water extract of Moringa oleifera leaf stalk on bacteria normally implicated in eye diseases. Academia Arena 2010; 2(6): 80-82.

Thilza IB, Sanni S, Zakari AFS, Sanni MT,
Musa BJ. In vitro antimicrobial activity of water extract of Moringa oleifera leaf stalk on bacteria normally implicated in eye diseases. Academia Arena 2010; 2(6): 80-82.

TP Cushine; AJ Lamb, Int. J. Antimicrobial. Agents, 2005 26(5): 343-356.

Trease GE, Evans WCX. Pharmacognosy. London: Bailliere Tindall; 1989, p 343383.

\section{How to cite this article:}

Nishu , Chandrawati Jee and Ravi Kumar . 2020. Phytochemical Screening and Antibacterial Assay of extracts of different parts of Moringa oleifera Lam. Int.J.Curr.Microbiol.App.Sci. 9(02): 1473-1481. doi: https://doi.org/10.20546/ijcmas.2020.902.170 